\title{
Metal content and distribution in surface sediments in an industrial region
}

\author{
ISMAEL L. SCHNEIDER ${ }^{1}$, ELBA C. TEIXEIRA ${ }^{1,2}$, MARIA LUCIA K. RODRIGUES $^{3}$ and SILVIA B.A. ROLIM ${ }^{1}$ \\ ${ }^{1}$ Programa de Pós-Graduação em Sensoriamento Remoto e Meteorologia, \\ Universidade Federal do Rio Grande do Sul, Av. Bento Gonçalves, 9500, 91501-970 Porto Alegre, RS, Brasil \\ ${ }^{2}$ Departamento de Pesquisa, Fundação Estadual de Proteção Ambiental Henrique Luis Roessler, \\ Av. Borges de Medeiros, 261, 90020-023 Porto Alegre, RS, Brasil \\ ${ }^{3}$ Fundação Estadual de Proteção Ambiental Henrique Luis Roessler, \\ Rua Aurélio Porto, 37, 90620-090 Porto Alegre, RS, Brasil
}

Manuscript received on April 11, 2013; accepted for publication on September 11, 2013

\begin{abstract}
The present study aimed to evaluate $\mathrm{Cu}, \mathrm{Cr}, \mathrm{Ni}, \mathrm{Zn}, \mathrm{Pb}, \mathrm{Mn}, \mathrm{Al}$, and Fe contents, as well as their geochemical partitioning in Sinos River basin sediments in southern Brazil. This basin is a densely populated area with a substantial number of industries, especially metallurgy, electroplating works, steel mills, petrochemicals, and tanneries. The total metal concentrations were determined by X-ray fluorescence and the sediment phase concentrations were determined by applying the BCR-701 sequential extraction method proposed by the Community Bureau of Reference of the European Community, using ICP/OES. The contents extracted by a solution of $0.5 \mathrm{~mol} / \mathrm{L} \mathrm{HCl}$ were also considered. Metal contents were evaluated in the sediment fraction $<63 \mu \mathrm{m}$. Results in the industrialized and densely populated region showed an increase in the total concentrations of $\mathrm{Cu}, \mathrm{Cr}, \mathrm{Zn}$, and $\mathrm{Pb}$, and in the potentially mobile fractions for $\mathrm{Cu}, \mathrm{Cr}, \mathrm{Zn}$ and $\mathrm{Ni}$ sequentially extracted. Cr stood out particularly in the Portão stream, showing $1,286 \mathrm{mg} / \mathrm{kg}$ as a result of the total concentration, considering the tannery region influence.
\end{abstract}

Key words: BCR-701, metals, sediment, sequential extraction.

\section{INTRODUCTION}

Metals are one of the most common pollutants in aquatic environments and may be originated from natural sources, from geological weathering or anthropogenic sources, such as industrial, agricultural, urban and domestic effluents (Hang et al. 2009, Davutluoglu et al. 2011). Metals when dispersed in aquatic environments tend to deposit in the sediments, which have high retention capacity and the potential of release these pollutants (Salomons and Stigliani 1995, Passos et al. 2011).

Correspondence to: Ismael Luís Schneider E-mail: ismaelquimrs@yahoo.com.br
This release into the overlying water column may occur by changes in environmental conditions such as $\mathrm{pH}$, redox potential, bioturbation and organic matter decomposition (Förstner and Kersten 1989, Davutluoglu et al. 2011). Nevertheless, the sediments act as reservoirs of metals, providing a reasonably accurate history of the pollution of the river (Sakai et al. 1986, Filgueiras et al. 2002, Hang et al. 2009, Davutluoglu et al. 2011).

However, the determination in metal total concentration in sediments is not a particularly good indicator when one looks for a distinction between natural and anthropogenic contributions 
(Quevauviller et al. 1996, Relic et al. 2010, Passos et al. 2011, Okoro et al. 2012). Thus, recent studies have used sequential extraction procedures to understand the specific chemical associations with sedimentary phases and metal sources (Rodrigues and Formoso 2006, Hang et al. 2009, Davutluoglu et al. 2011). Many of these are variants on the scheme proposed by Tessier et al. (1979). These procedures use selective reagents to consecutively extract "operationally defined phases" from the sediments, allowing for the quantification of the levels of potentially mobile metals and the establishment of associations with anthropogenic contributions (Rauret et al. 1999, Larner et al. 2008). Thus, alterations in the environmental conditions are simulated, enabling the prediction of the impact of a potential mobilization of metals on the surrounding environment (Bacon and Davidson 2008). The quantification of potentially mobile metals can also be done by simple extraction techniques (Gleyzes et al. 2002).

Currently, one technique often used is the sequential extraction procedure proposed by the Community Bureau of Reference (BCR) (now called Standards, Measurement and Testing Programme). This procedure was developed in order to solve the lack of sequential extraction procedure uniformity. Besides that, it provides a corresponding certified reference material and gives a method validation and a way of comparing the data generated (LópezSánchez et al. 1998, Rauret et al. 1999). This technique involves three steps - exchangeable metals associated with carbonates, reducible metals, and oxidizable metals (Quevauviller et al. 1996, Rauret 1998, Davidson et al. 1999, Pueyo et al. 2001, Teixeira et al. 2003, Rodrigues and Formoso 2006, Boughriet et al. 2007, Davutluoglu et al. 2011, Passos et al. 2011, Dundar et al. 2012).

Some problems have not yet been fully resolved in the use of sequential extractions, such as redistribution of analytes between the geochemical phases, lack of reagent selectivity, incomplete extraction and precipitation of new mineral phases during the extraction. Even so, the increasing use of such schemes in the evaluation of metals in sediments has shown the usefulness of the information obtained, which many times corresponds to observable environmental effects, such as the decrease in local biodiversity (Rauret et al. 1999, Julián and Collado 2002, Bacon and Davidson 2008, Rodrigues et al. 2008).

On the other hand, to evaluate the potentially mobile metals, cold acid extraction procedures may also be used, which tries to simulate the natural removal processes of these more "reactive" elements of the sediments (Bevilacqua et al. 2009). The extraction procedure with diluted hydrochloric acid $(\mathrm{HCl})$ has been frequently applied (Sutherland and Tack 2008, Bevilacqua et al. 2009, Li et al. 2009) and can be used as a first evaluation technique for monitoring the potential contamination by metals. Then, high levels identified by the extraction with $\mathrm{HCl}$ may be subject to further assessment, using sequential extraction procedures (Sutherland and Tack 2008).

Sinos River basin is located in an industrialized and densely populated area, where there are metallurgical industries, electroplating works, steel mills, petrochemicals and tanneries, liquid waste generators with metals. Even though sediment contamination is currently one of the most serious problems in basin environmental management, finding solutions for these problems is still poor. Robaina et al. (2002) and Oliveira et al. (2008) have studies that show an intense metal contamination in the lower Sinos River.

The aim of this study is to evaluate the geochemical distribution and potential mobility of some metals $(\mathrm{Cu}, \mathrm{Cr}, \mathrm{Ni}, \mathrm{Zn}, \mathrm{Pb}, \mathrm{Mn}, \mathrm{Al}$, and $\mathrm{Fe})$ in sediments along the Sinos River basin. These metals were selected because they indicate the industrial liquid waste markers which are located in the study area especially in the metallurgical/ electroplanting and tannery sectors $(\mathrm{Cu}, \mathrm{Zn}, \mathrm{Ni}, \mathrm{Pb}$ and $\mathrm{Cr}$ ), as well as natural components in the area (such as $\mathrm{Mn}, \mathrm{Al}$ and $\mathrm{Fe}$ ). 


\section{STUDY AREA}

Sinos River basin is located in the northeast of the state of Rio Grande do Sul, Brazil, with an extension of $3,820 \mathrm{~km}^{2}$ crossing almost 29 counties, of which 21 are within the Porto Alegre Metropolitan Area, the capital of the state (see Fig. 1). It is bounded to the east by the Serra Geral, to the west and north by the Caí River basin, and to the south by the Gravataí River basin. Sinos River has its source at an altitude of $600 \mathrm{~m}$, its main course flows is $190 \mathrm{~km}$ and it finally discharges at an altitude of $12 \mathrm{~m}$. About 1.3 million people inhabit its basin (Comitesinos 2009), representing $13 \%$ of the total population of the state concentrated in only $3.5 \%$ of its territory. The climate is subtropical with an annual average temperature of around $20^{\circ} \mathrm{C}$ and about 1,600 $\mathrm{mm}$ of rain annually, well-distributed over the four seasons (FEPAM 2006).

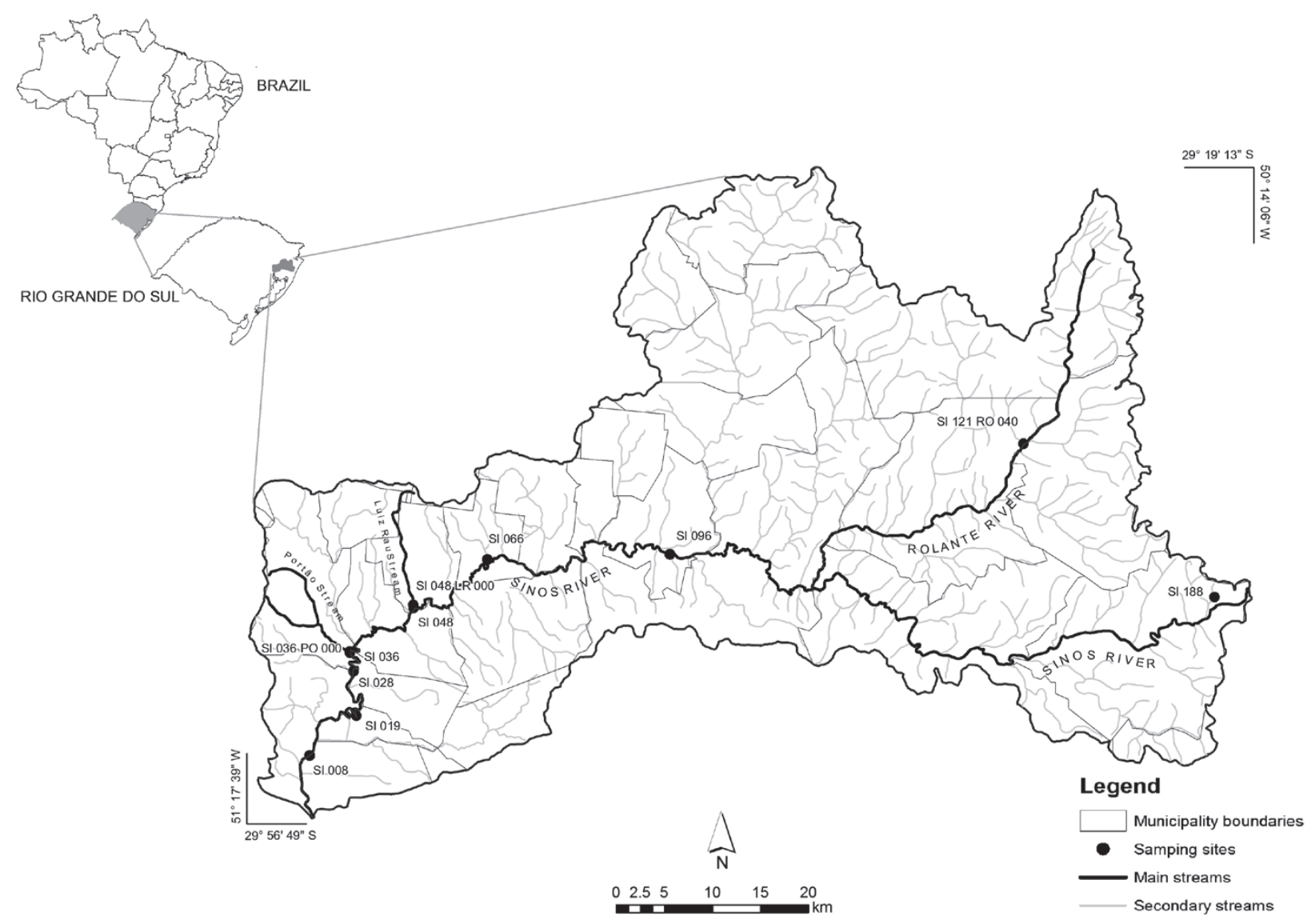

Fig. 1 - Study area with the sampling sites in the Sinos River basin.

The basin can be divided into three different regions, all of which related to the corresponding section of the river: upper, middle, and lower. In the upper part, characterized by a more rugged terrain and by agricultural activities in small farms, we selected two sampling sites (Table I). This part of the Sinos River, about $25 \mathrm{~km}$ long, has high declivity, with altitudes ranging between $600 \mathrm{~m}$ and $60 \mathrm{~m}$. In the middle section of the basin, with about $125 \mathrm{~km}$, the declivity of the Sinos River decreases, and we chose one sampling site (Table I). As one moves downstream, the population density and 
urbanization as well as the industrial concentration increase. Presently, industrial activity (especially metallurgy, electroplating works, steel mills, petrochemicals and tanneries), domestic sewage, and rice farming are the main sources of concern with regard to water quality of this river basin (FEPAM 2006). The lower stretch of the Sinos River has, as major tributaries, streams that drain large urban centers, such as the Luiz Rau and the Portão streams. Besides choosing sampling sites near the mouth of these streams, we also selected six additional sites along the main course of the Sinos River (Table I). The codes of the locations indicate the distance in kilometers from the sampling location to the mouth of the Sinos River.

TABLE I

Location of the sediment sampling sites.

\begin{tabular}{cccc}
\hline Site & \multicolumn{2}{c}{ Coordinates } & Stretch of river \\
& X & Y & \\
\hline SI 188 & -50.263 & -29.725 & Upper \\
Rolante river & -50.470 & -29.581 & Upper \\
SI 096 & -50.850 & -29.686 & Middle \\
SI 066 & -51.046 & -29.691 & Lower \\
Luiz Rau stream & -51.126 & -29.734 & Lower \\
SI 048 & -51.126 & -29.737 & Lower \\
Portão stream & -51.195 & -29.778 & Lower \\
SI 036 & -51.194 & -29.779 & Lower \\
SI 028 & -51.191 & -29.796 & Lower \\
SI 019 & -51.188 & -29.838 & Lower \\
SI 008 & -51.238 & -29.875 & Lower \\
\hline
\end{tabular}

MATERIALS AND METHODS

Collection AND PREPARATION OF SAMPleS

Sediment samples were collected between February and August 2010, at eight locations along the main course of the Sinos River and three tributaries (Rolante River and the mouths of Luiz Rau and Portão streams). Samples of surface sediments were collected by using a PVC, L-shaped manual collector. The material collected was stored in plastic bags, cooled to $4{ }^{\circ} \mathrm{C}$ and sent to the laboratory, where the fraction with particle size $<63 \mu \mathrm{m}$ was separated by means of wet sieving. This procedure was performed on the same day of sampling, thereby to minimize the action of microorganisms in migration processes and avoid metals redistribution. The interest content was ovendried at $37^{\circ} \mathrm{C}$ and was then finely homogenized in an agate mortar.

\section{CHEMICAL ANALYSES}

\section{Total metal concentration}

To evaluate the total metal concentrations, the sediment samples were prepared as compressed pellets and analyzed in a sequential X-ray fluorescence spectrometer (PW2404, Philips), equipped with a rhodium tube. The analysis was performed at the Analytical Geochemistry Laboratory at Campinas University.

\section{Sequential extraction}

The fractional metal concentrations in the geochemical phases of the sediments was carried out according to the sequential extraction method proposed by the BCR (now Standards, Measurement and Testing Programme) (Pueyo et al. 2001, Teixeira et al. 2003, Rodrigues and Formoso 2006, Davutluoglu et al. 2011, Passos et al. 2011, Dundar et al. 2012). The procedure is explained in Table II. The quantification of metallic cations in solution was performed in an inductively coupled plasma optical emission spectrometer (ICP-OES) at the Soils Laboratory of the Federal University of Rio Grande do Sul. In this study, the fourth stage, corresponding to the metal residual fraction, was determined by the difference between the sum of the three sequentially extracted stages in relation to the total content of the metal under study, previously obtained by X-ray fluorescence.

\section{Extraction with $0.5 \mathrm{~mol} / \mathrm{L} \mathrm{HCl}$}

The analysis of potentially mobile metals extracted with a solution of $0.5 \mathrm{~mol} / \mathrm{L} \mathrm{HCl}$ was performed as recommended by Sutherland (2002) and Sutherland and Tack $(2007,2008)$. The procedure involved the extraction of $0.5 \mathrm{~g}$ of sample with $10 \mathrm{~mL}$ of a 
TABLE II

The BCR sequential extraction procedure.

\begin{tabular}{|c|c|c|c|}
\hline STEPS & REAGENTS & PROCEDURE & SEDIMENT PHASES \\
\hline 1 & Acetic acid $0.11 \mathrm{~mol} / \mathrm{L}$ & $\begin{array}{c}1 \mathrm{~g} \text { of sample }+40 \mathrm{~mL} \text { of } \mathrm{CH}_{3} \mathrm{COOH} \\
\text { stirred for } 16 \mathrm{~h} \text { at } 30 \mathrm{rpm}\end{array}$ & $\begin{array}{l}\text { Exchangeable - water } \\
\text { soluble species and acid }\end{array}$ \\
\hline 2 & $\begin{array}{l}0.10 \mathrm{~mol} / \mathrm{L} \text { hydroxylamine } \\
\text { hydrochloride, } \mathrm{pH} 1.5\end{array}$ & $\begin{array}{l}\text { Residue of step } 1+40 \mathrm{~mL} \text { of } \mathrm{NH}_{2} \mathrm{OH} \text {. } \\
\mathrm{HCl} \text { stirred for } 16 \mathrm{~h} \text { at } 30 \mathrm{rpm}\end{array}$ & $\begin{array}{c}\text { Reducible - species bound } \\
\text { to Fe and Mn oxides and } \\
\text { hydroxides }\end{array}$ \\
\hline 3 & $\begin{array}{c}1.0 \mathrm{~mol} / \mathrm{L} \text { ammonium acetate, after } \\
\text { digestion with } 8.8 \mathrm{~mol} / \mathrm{L} \text { hydrogen } \\
\text { peroxide at } \mathrm{pH} 2\end{array}$ & $\begin{array}{c}\text { Residue of step } 2+20 \mathrm{~mL} \text { of } \mathrm{H}_{2} \mathrm{O}_{2} \\
\text { at } 85^{\circ} \mathrm{C} \text { almost until dry; } 50 \mathrm{~mL} \\
\mathrm{CH}_{3} \mathrm{COONH}_{4} \text { stirred for } 16 \mathrm{~h} \text { at } 30 \mathrm{rpm}\end{array}$ & $\begin{array}{c}\text { Oxidizable }- \text { species bound } \\
\text { to organic matter and } \\
\text { sulfides }\end{array}$ \\
\hline $4^{*}$ & $\begin{array}{l}\text { Total concentration minus the sum } \\
\text { of the previous three steps }\end{array}$ & & $\begin{array}{l}\text { Residual - species bound to } \\
\text { the silicate matrix }\end{array}$ \\
\hline
\end{tabular}

Source: Adapted from Davutluoglu et al. (2011). *Adopted herein.

solution of $0.5 \mathrm{~mol} / \mathrm{L} \mathrm{HCl}$ under continuous stirring at $200 \mathrm{rpm}$ for $1 \mathrm{~h}$ at $20^{\circ} \mathrm{C}$. The suspension obtained was filtered through cellulose ester filter of 0.20 $\mathrm{mm}$ porosity prior to quantification of $\mathrm{Cu}, \mathrm{Cr}, \mathrm{Ni}$, $\mathrm{Pb}$, and $\mathrm{Zn}$, certified for the reference material BCR-701. The quantification of metallic cations in solution was performed in an ICP-OES at the Soils Laboratory of the Federal University of Rio Grande do Sul. Subsequently, the contents extracted by $0.5 \mathrm{~mol} / \mathrm{L} \mathrm{HCl}$ solution and those by sequential extraction were correlated by regressions.

\section{General CHARACTERISTICS OF THE SEDIMENTS}

Total sulfur (S) was determined by X-ray fluorescence and corresponds to indicative values. Organic matter was obtained by the loss of mass by ignition ( $2 \mathrm{~h}$ at $360^{\circ} \mathrm{C}$ ) (Schulte and Hopkins 1996). The analysis of particle size was performed in the laboratory of the Center for Coastal Studies (CECO) of the Federal University of Rio Grande do Sul and it involved the separation of the main textural classes of sediments by sieving and sedimentation techniques. The clay minerals were also analyzed at the CECO, after preparation of slides with the oriented clay minerals. The slides were air-dried, solvated with ethylene glycol and calcinated, and were then successively analyzed by an X-ray diffractometer in the range of between $2 \theta 2-28^{\circ}$, by using $\mathrm{CuK} \alpha$ radiation.

\section{ACCURACY OF THE CHEMICAL ANALYSIS}

To assess the accuracy of the total metals concentrations, two soil reference materials were used (GSS-2 and GSS-5, China), showing mean recoveries from 88 to $105 \%$ for $\mathrm{Cr}, \mathrm{Cu}, \mathrm{Ni}, \mathrm{Pb}, \mathrm{Zn}, \mathrm{MnO}, \mathrm{Al}_{2} \mathrm{O}_{3}$, and $\mathrm{Fe}_{2} \mathrm{O}_{3}$. The metal concentrations determination in the reference material was performed in duplicate, with coefficients of variation $<10 \%$. The detection limits (DL) for $\mathrm{Cr}, \mathrm{Cu}, \mathrm{Ni}, \mathrm{Pb}$ and $\mathrm{Zn}$ were 3, 2, 2 , 3 and $2 \mathrm{mg} / \mathrm{kg}$, respectively.

One certified sediment reference material (BCR-701) was analyzed to determine the accuracy of the sequential extraction procedure described above. The certified and analyzed values and their recoveries at each extraction step were calculated with mean recoveries from 85 to $104 \%$ for $\mathrm{Cr}$, $\mathrm{Cu}, \mathrm{Ni}, \mathrm{Pb}$, and $\mathrm{Zn}$. The analyses of this certified reference material were performed in triplicate and of the sediment samples in duplicate, showing coefficients of variation $<10 \%$. The detection limits (DL) for $\mathrm{Cr}, \mathrm{Cu}, \mathrm{Ni}, \mathrm{Pb}$ and $\mathrm{Zn}$ were $0.4,0.6,0.4$, 2.0 and $2.0 \mathrm{mg} / \mathrm{kg}$, respectively.

For the extraction procedure with a solution of $0.5 \mathrm{~mol} / \mathrm{L} \mathrm{HCl}$, one of the samples was spiked with a known amount of each metal evaluated $(\mathrm{Cr}, \mathrm{Cu}$, $\mathrm{Ni}, \mathrm{Pb}$ and $\mathrm{Zn}$ ) and then analyzed in triplicate, with average recoveries of $91-97 \%$. The determination of metal concentrations in the sediment samples was performed in duplicate, with coefficients of 
variation $<10 \%$. The detection limits (DL) for $\mathrm{Cr}$, $\mathrm{Cu}, \mathrm{Ni}, \mathrm{Pb}$ and $\mathrm{Zn}$ were 0.4, 0.6, 0.4, 2.0 and 2.0 $\mathrm{mg} / \mathrm{kg}$, respectively.

\section{SEDIMENT QUALITY ASSESSMENT}

The total concentrations of metal in the Sinos River basin sediments were compared with the specific literature: taking the studied background concentrations (Robaina et al. 2002), average shale (Turekian and Wedepohl 1961), and other metals levels in rivers around the globe (Irabien and Velasco 1999, Rodrigues and Formoso 2006, Boughriet et al. 2007, Li et al. 2009, Davutluoglu et al. 2011, Hang et al. 2009, Rangel et al. 2011, Dundar et al. 2012).

To assess the ecotoxicological implications of total metal concentrations in sediments, we considered sediment quality guidelines (SQGs) as: the indices established by the Canadian Council of Ministers of the Environment (CCME 1999) and the study of Long et al. (1995).

Long et al. (1995) define two sets: i) effects range low (ERL)/effects range median (ERM) and ii) the threshold effects level (TEL)/probable effects level (PEL). ERL and TEL indices refer to concentrations below which adverse effects on the wildlife in the sediment are unlikely and which would be expected only infrequently. In contrast, adverse effects are more likely to occur when metal concentrations are above ERM and PEL. The Canadian study reports the indices interim freshwater sediment quality guideline (ISQG) and probable effects level (PEL).

\section{STATISTICAL ANALYSIS}

Principal component analysis (PCA) was applied to the set of variables in the sediments in order to estimate potential emission sources. Chemical variables used in PCA were selected based on the Pearson correlation matrix, giving rise to a set of synthetic variables (principal components) based on the interrelationships of the original data. The principal components selected were those that obtained characteristic roots $>1.0$ after applying the Varimax rotation. The primary function of the PCA is a decrease in the number of variables while retaining the original information as much as possible, and thus variables with similar characteristics can be grouped into factors. PCA was analyzed by using Windows SPSS version 20.0.

\section{RESULTS AND DISCUSSION}

GENERAL CHARACTERISTICS OF THE SEDIMENTS

Table III shows the general characteristics of the sediments. The highest sulfur levels (S) were found at the sites near the mouth of the Sinos River (SI 019 and SI 008) and the Portão stream, while the highest organic matter (OM) were found at sites SI 188 (16.8\%) and Portão stream (15.8\%). The high OM content observed at the source of the Sinos River (SI 188) can be attributed to the influence of well-preserved vegetation of the river margins. At the same place a high content of sulfur was also noticed, which may be locally released during organic matter decomposition (Neue and Mamaril 1985). The OM is considered a metal geochemical carrier in some types of environments due to its capacity of absorbing and complexing metals of both terrestrial and marine origins (Salomons and Förstner 1984, Warren and Haack 2001).

Sinos River sediment grain is composed by gravel (from $0 \%$ to $75 \%$ ), sand (from $16 \%$ to $98 \%$ ), silt (from $1 \%$ to $62 \%$ ) and clay (from $1 \%$ to $20 \%$ ). The coarse sediments were found at sites SI 188 and Rolante River, in the upper part of the river basin, indicating its proximity to the bedrock. The texture of the sediments (Table III) was predominantly sand, except for site SI 028, which showed $61.7 \%$ of silt. According to Laybauer and Bidone (2001), at sites with a greater incidence of smaller particle sizes, which have an increase in the superficial area and the capacity of the cations exchange, there will be a tendency of metal accumulation in the 
TABLE III

Additional parameters used for characterizing sediment samples from the Sinos River basin.

\begin{tabular}{|c|c|c|c|c|c|c|c|c|}
\hline \multirow{2}{*}{ Site } & \multicolumn{4}{|c|}{ Particle size fraction $(\%)$} & \multirow{2}{*}{$\begin{array}{l}\text { Particle size } \\
\text { classification }\end{array}$} & \multirow{2}{*}{$\mathrm{S}(\mathrm{mg} / \mathrm{kg})$} & \multirow{2}{*}{$\mathrm{OM}(\%)$} & \multirow{2}{*}{ Clay minerals } \\
\hline & gravel & sand & silt & clay & & & & \\
\hline SI 188 & 75.0 & 16.2 & 7.7 & 1.0 & gravel and sand & 764 & 16.8 & smectite, illite, quartz, zeolite \\
\hline Rolante river & 12.8 & 84.6 & 1.9 & 0.8 & sand & 394 & 10.6 & $\begin{array}{l}\text { kaolinite, smectite, illite, } \\
\text { k-feldspar, quartz }\end{array}$ \\
\hline SI 096 & 0.0 & 48.8 & 34.5 & 16.7 & mud with sand & 224 & 8.7 & $\begin{array}{c}\text { kaolinite, smectite, k-feldspar, } \\
\text { quartz }\end{array}$ \\
\hline SI 066 & 0.0 & 46.0 & 41.6 & 12.4 & mud with sand & 511 & 12.1 & $\begin{array}{c}\text { kaolinite, smectite, k-feldspar, } \\
\text { quartz }\end{array}$ \\
\hline Luiz Rau stream & 0.0 & 75.8 & 15.3 & 8.9 & sand & 267 & 11.1 & kaolinite, smectite, illite, quartz \\
\hline SI 048 & 0.0 & 71.3 & 19.5 & 9.2 & sand with mud & 286 & 10.0 & $\begin{array}{c}\text { kaolinite, smectite, k-feldspar, } \\
\text { quartz }\end{array}$ \\
\hline Portão stream & 0.0 & 98.3 & 0.6 & 1.1 & sand & 922 & 15.8 & barite, kaolinite smectite, quartz \\
\hline SI 036 & 0.0 & 92.7 & 4.6 & 2.7 & sand & 637 & 9.8 & $\begin{array}{c}\text { kaolinite, smectite, illite, } \\
\text { k-feldspar, quartz }\end{array}$ \\
\hline SI 028 & 0.0 & 18.0 & 61.7 & 20.3 & mud & 729 & 11.5 & kaolinite, smectite, quartz \\
\hline SI 019 & 0.0 & 66.1 & 25.4 & 8.5 & sand with mud & 1301 & 12.0 & $\begin{array}{c}\text { kaolinite, smectite, k-feldspar, } \\
\text { quartz }\end{array}$ \\
\hline SI 008 & 0.0 & 52.2 & 37.4 & 10.3 & sand with mud & 1205 & 11.5 & kaolinite, smectite, illite, quartz \\
\hline
\end{tabular}

sediments. Assuming the grain composition, the samples were classified into gravel and sand, sand, mud with sand, sand with mud and mud.

Concerning mineralogical analyses, quartz, kaolinite and smectite are scattered over the entire river basin (Table III), except for kaolinite at the Sinos River source (SI 188). According to Rodrigues and Formoso (2006), sediments containing smectite (expansive clays of high cation exchange capacity) can retain metals, which are subject to remobilization under changes in environmental conditions. Furthermore, illite, zeolite, $\mathrm{K}$-feldspar, and barite were also identified. These minerals were probably formed by alteration of volcanic rocks of the Serra Geral Formation and sandstones of the Botucatu Formation (Oliveira et al. 2008).

\section{STATISTICAL ANALYSIS}

Table V shows the factorial weight matrix obtained from total metals concentrations in sediments from the Sinos River basin sampling. Factor analysis performed with the variables explained $43.2 \%$ for
Factor 1, 22.9\% for Factor 2 and 18.8\% for Factor 3 of total variance. These three factors explain $84.9 \%$ of the total variance of the data.

Factor 1 explained $43.2 \%$ of the total variance of the data and had positive loadings on $\mathrm{Cu}(0.813), \mathrm{Pb}$ (0.923), $\mathrm{Zn}(0.704)$ and Al (0.869). This factor shows these metals are from electroplating industries in which these metals are used in deposition processes and beyond aesthetic reasons, where they work in abrasion resistance and corrosion. According to Factor 1, Mn (-0.763), Fe (-0.742) and Ni (-0.636) show negative loadings and its main reason is the metallurgical and steel industries. These industries use Mn-Fe-Ni alloys in their production processes. About 70 industries are located in the Sinos River basin, and are classified into basic metallurgy and they may be responsible for the heavy metals found in Factor 1.

Factor 2 explained $22.9 \%$ of the total variance, showing loadings on $\mathrm{Cr}(0.977)$ and $\mathrm{OM}(0.658)$ that might be identified as originating from tanneries in the Sinos River basin. Other papers have reported $\mathrm{Cr}$ to $\mathrm{OM}$ association (Rodrigues and Formoso 
2006, Oliveira et al. 2008, Rangel et al. 2011). This association is based on the sequential extraction, where $\mathrm{Cr}$ is associated to step 3 (sulfides/OM).

Factor 3 explained $18.8 \%$ of total variance, with positive loadings on $\mathrm{Zn}(0.658)$ and $\mathrm{S}(0.952)$. This leads to $\mathrm{Zn}$ labor in the oxidizable fraction (step 3) of the sequential extraction procedure such as sulfides, further analyzed in this paper.

\section{TOTAL CONTENTS AND METAL Fractionation}

Table IV shows the results of metal concentrations in sediments (fraction $<63 \mu \mathrm{m}$, dry weight) of the Sinos River and its tributaries and Fig. 2 shows the percentage distribution of the selected metals in the four geochemical sediment phases. The average potential availability in relation to total metal content, as measured by the sum of the three mobile phases of the BCR sequential procedure, showed some differences between the river basin subdivisions. In the upper stretch, the following metal sequence bioavailability was observed: $\mathrm{Mn}$ $(71 \%)>\mathrm{Pb}(54 \%)>\mathrm{Zn}(26 \%)>\mathrm{Cr}(13 \%)>\mathrm{Cu}$ $(12 \%)>\mathrm{Ni}(11 \%)>\mathrm{Fe}(9 \%)>\mathrm{Al}(5 \%)$. For the middle stretch, the sequence was $\mathrm{Mn}(43 \%)>\mathrm{Pb}$ $(42 \%)>\mathrm{Cu}(14 \%)>\mathrm{Zn}(13 \%)>\mathrm{Cr}(12 \%)>\mathrm{Ni}$ $(8 \%)>\mathrm{Fe}(5 \%)>\mathrm{Al}(4 \%)$. For the lower stretch, the sequence was $\mathrm{Mn}(76 \%)>\mathrm{Zn}(65 \%)>\mathrm{Pb}$ $(51 \%)>\mathrm{Cr}(46 \%)>\mathrm{Ni}(45 \%)>\mathrm{Cu}(41 \%)>\mathrm{Fe}$ $(17 \%)>\mathrm{Al}(4 \%)$. Some differences were observed in the sequence of mobility potential in the three parts of the river basin, so that in the lower part, which shows a higher concentration of industries and habitants, there is an increase in potentially mobile fractions of $\mathrm{Zn}, \mathrm{Cr}, \mathrm{Ni}, \mathrm{Cu}$, and $\mathrm{Fe}$.

$\mathrm{Fe}$ and $\mathrm{Al}$ showed high percentages in the residual phase (Fig. 2) in all basin samples, indicating that these elements have a low mobility in the environment where they are and that they are little affected by human activity (Li et al. 2009). The presence of the minerals kaolinite, smectite, illite, quartz (Table III) and hematite (Oliveira et al. 2008) endorse these elements in the residual stage.
$\mathrm{Cu}$ total concentrations (Table IV) varied from 69 to $121 \mathrm{mg} / \mathrm{kg}$, and the maximum values were found in the Luiz Rau stream, followed by sites from the point SI 028 onwards. As for the potential mobility (Fig. 2), there is an increase onwards site SI 066, located at the beginning of the lower part of the basin. The most affected site is the Luiz Rau stream $(121 \mathrm{mg} / \mathrm{kg})$, where the potentially mobile phases reached $62 \%$ of the total content. This stream receives all discharges from one of the main urban centers and around its site there are electroplating, metallurgical and chemical industries. $\mathrm{Cu}$ was extracted mainly in reducible (1-24\%) and oxidized (6-29\%) fractions of the sequential extraction procedure, according to results from other studies that evaluated urban and industrial influences (Davidson et al. 1994, Kubová et al. 2008, Davidson et al. 2006, Rodrigues and Formoso 2006, Hang et al. 2009, Li et al. 2009, Vymazal et al. 2010, Davutluoglu et al. 2011). In addition, a high percentage in the exchangeable phase $(21 \%)$ was also observed in the Luiz Rau stream, in accordance to studies by Irabien and Velasco (1999), Hang et al. (2009), and Liu et al. (2009). The increase of $\mathrm{Cu}$ in the oxidizable stage is related to sulfur increasing (see Table III) in the lower of the Sinos River, indicating this metal appearance as sulfides. According to Pedrozo (2003), the copper bioavailability decreases with the complexities and absorption of this element to the organic matter/sulfur and to $\mathrm{Fe} / \mathrm{Mn}$ oxyhydroxides.

Zn concentrations (Table IV) ranged from 112 to $316 \mathrm{mg} / \mathrm{kg}$, with an increase in the lower part of the Sinos River basin, in particular at the sites of the Luiz Rau stream, SI 019, and SI 008. That corresponds to the low course of the river where the sediments are deposited due to low water energy. According to Horowitz (1991) and Miller (1997), environments characterized by calm waters and thin particles tend to show high metal concentration, if compared to deposits associated to high energy regimes and thicker sediments. In this same part, there is also an increase in the potential mobility of Zn (Fig. 2), which increased from about 28\% (SI 


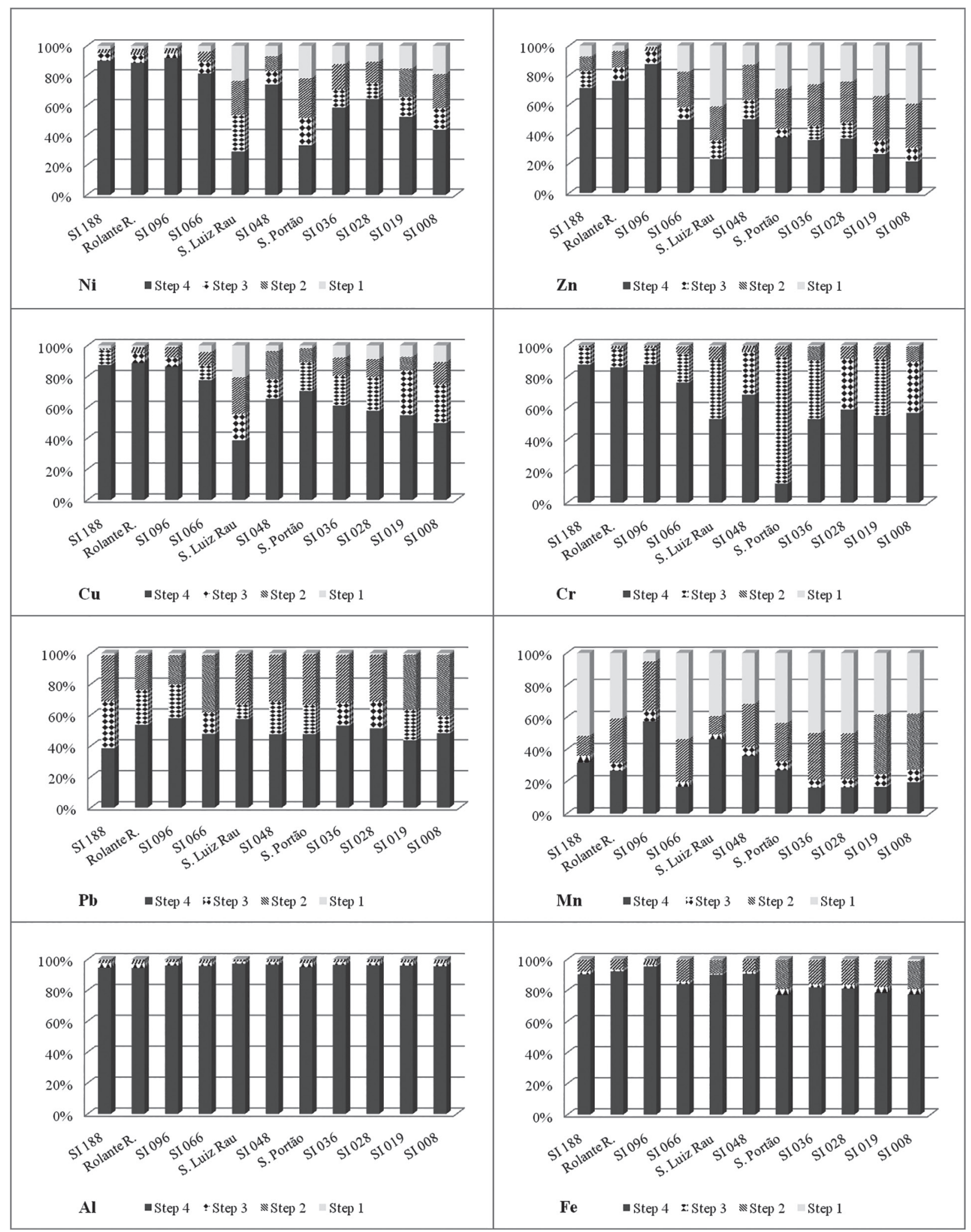

Fig. 2 - Geochemical distribution of $\mathrm{Ni}, \mathrm{Zn}, \mathrm{Cu}, \mathrm{Cr}, \mathrm{Pb}, \mathrm{Mn}, \mathrm{Al}$ and $\mathrm{Fe}$ in the Sinos River basin sediments (Step $1=$ available fraction, i.e., exchangeable and bound to carbonates; Step 2 = reducible fraction; Step 3 = oxidizable fraction; Step $4=$ residual fraction). 
TABLE IV

Metals concentrations for the sequential extraction procedure BCR, extraction with $0.5 \mathrm{~mol} / \mathrm{L} \mathrm{HCl}$ and total contents with $\mathrm{XRF}$.

\begin{tabular}{|c|c|c|c|c|c|c|c|c|c|}
\hline Site & $\begin{array}{l}\text { Procedure } \\
\text { analytical }\end{array}$ & $\begin{array}{c}\mathrm{Cu} \\
\mathrm{mg} / \mathrm{kg}\end{array}$ & $\begin{array}{c}\mathrm{Zn} \\
\mathrm{mg} / \mathrm{kg}\end{array}$ & $\begin{array}{c}\mathrm{Ni} \\
\mathrm{mg} / \mathrm{kg}\end{array}$ & $\begin{array}{c}\mathrm{Cr} \\
\mathrm{mg} / \mathrm{kg}\end{array}$ & $\begin{array}{c}\mathrm{Pb} \\
\mathrm{mg} / \mathrm{kg}\end{array}$ & $\begin{array}{c}\mathrm{Al} \\
\mathrm{mg} / \mathrm{g}\end{array}$ & $\begin{array}{c}\mathrm{Fe} \\
\mathrm{mg} / \mathrm{g}\end{array}$ & $\begin{array}{c}\mathrm{Mn} \\
\mathrm{mg} / \mathrm{g}\end{array}$ \\
\hline \multirow[t]{6}{*}{ SI 188} & Step 1 & 1.50 & 9.76 & 0.89 & 0.31 & $<2.0$ & 0.19 & 0.28 & 0.55 \\
\hline & Step 2 & $<0.60$ & 13.2 & 0.98 & 1.32 & 8.24 & 2.19 & 6.57 & 0.13 \\
\hline & Step 3 & 6.87 & 15.2 & 2.06 & 13.2 & 8.32 & 2.78 & 1.45 & 0.04 \\
\hline & Step 4 & 60.9 & 94.1 & 35.2 & 106 & 10.6 & 91.2 & 77.6 & 0.34 \\
\hline & $0.5 \mathrm{M} \mathrm{HCl}$ & - & - & - & - & - & - & - & - \\
\hline & Total & 69.8 & 132 & 39.2 & 121 & 27.5 & 96.4 & 85.9 & 1.07 \\
\hline Rolante & Step 1 & 0.87 & 4.55 & 1.11 & 0.39 & $<2.0$ & 0.07 & 0.04 & 0.74 \\
\hline \multirow[t]{5}{*}{ River } & Step 2 & 2.87 & 13.5 & 2.15 & 2.10 & 5.68 & 2.54 & 5.67 & 0.50 \\
\hline & Step 3 & 4.71 & 10.9 & 2.91 & 13.3 & 5.74 & 2.32 & 0.99 & 0.09 \\
\hline & Step 4 & 65.8 & 92.0 & 47.9 & 96.6 & 13.6 & 83.2 & 79.4 & 0.48 \\
\hline & $0.5 \mathrm{M} \mathrm{HCl}$ & 16.2 & 13.8 & 2.37 & 1.84 & 7.02 & - & - & - \\
\hline & Total & 74.2 & 121 & 54.1 & 112 & 25.4 & 88.1 & 86.1 & 1.81 \\
\hline \multirow[t]{6}{*}{ SI 096} & Step 1 & 0.77 & 1.17 & 0.73 & 0.18 & $<2.0$ & 0.02 & 0.00 & 0.06 \\
\hline & Step 2 & 4.59 & 2.77 & 1.38 & 1.84 & 5.22 & 1.73 & 3.02 & 0.36 \\
\hline & Step 3 & 4.24 & 10.1 & 1.31 & 12.3 & 6.06 & 2.19 & 0.78 & 0.07 \\
\hline & Step 4 & 59.6 & 97.6 & 38.1 & 101.6 & 16.0 & 92.9 & 77.4 & 0.66 \\
\hline & $0.5 \mathrm{M} \mathrm{HCl}$ & 11.5 & 6.23 & 1.43 & 0.80 & 3.64 & - & - & - \\
\hline & Total & 69.2 & 112 & 41.5 & 116 & 27.7 & 96.9 & 81.2 & 1.15 \\
\hline \multirow[t]{6}{*}{ SI 066} & Step 1 & 3.31 & 26.6 & 1.92 & 0.79 & $<2.0$ & 0.07 & 0.19 & 1.02 \\
\hline & Step 2 & 6.46 & 36.1 & 3.28 & 6.71 & 11.1 & 2.31 & 9.92 & 0.51 \\
\hline & Step 3 & 7.29 & 12.5 & 3.73 & 25.2 & 4.16 & 1.90 & 1.10 & 0.05 \\
\hline & Step 4 & 58.7 & 74.2 & 39.1 & 105 & 14.2 & 95.2 & 59.0 & 0.32 \\
\hline & $0.5 \mathrm{M} \mathrm{HCl}$ & 29.1 & 48.4 & 3.74 & 5.95 & 11.3 & - & - & - \\
\hline & Total & 75.8 & 149 & 48.0 & 138 & 29.9 & 99.4 & 70.2 & 1.90 \\
\hline \multirow{6}{*}{$\begin{array}{l}\text { Luiz Rau } \\
\text { stream }\end{array}$} & Step 1 & 25.1 & 120 & 8.23 & 1.14 & $<2.0$ & 0.13 & 0.20 & 0.16 \\
\hline & Step 2 & 28.8 & 66.6 & 7.98 & 10.6 & 19.4 & 1.60 & 4.75 & 0.05 \\
\hline & Step 3 & 20.6 & 36.8 & 8.51 & 48.4 & 5.70 & 1.54 & 0.31 & 0.01 \\
\hline & Step 4 & 46.6 & 66.3 & 10.2 & 68.1 & 34.0 & 113 & 47.2 & 0.18 \\
\hline & $0.5 \mathrm{M} \mathrm{HCl}$ & 87.2 & 139.1 & 12.0 & 10.5 & 19.1 & - & - & - \\
\hline & Total & 121 & 289.2 & 34.9 & 128 & 59.5 & 116 & 52.4 & 0.40 \\
\hline \multirow[t]{6}{*}{ SI 048} & Step 1 & 2.87 & 22.8 & 3.03 & 0.50 & $<2.0$ & 0.03 & 0.01 & 0.44 \\
\hline & Step 2 & 14.4 & 41.8 & 4.42 & 6.74 & 11.6 & 1.58 & 5.61 & 0.38 \\
\hline & Step 3 & 9.88 & 22.6 & 3.79 & 43.6 & 8.04 & 1.69 & 0.85 & 0.08 \\
\hline & Step 4 & 51.2 & 87.4 & 32.1 & 111 & 18.1 & 94.7 & 62.4 & 0.50 \\
\hline & $0.5 \mathrm{M} \mathrm{HCl}$ & 32.9 & 48.8 & 5.68 & 5.16 & 11.6 & - & - & - \\
\hline & Total & 78.3 & 175 & 43.4 & 162 & 38.1 & 98.0 & 68.9 & 1.39 \\
\hline Portão & Step 1 & 1.62 & 66.5 & 11.0 & 5.91 & $<2.0$ & 0.08 & 0.13 & 0.18 \\
\hline \multirow[t]{3}{*}{ stream } & Step 2 & 7.63 & 61.6 & 13.4 & 87.9 & 16.5 & 2.20 & 7.95 & 0.10 \\
\hline & Step 3 & 15.5 & 13.3 & 9.12 & 1038 & 9.48 & 2.51 & 1.54 & 0.02 \\
\hline & Step 4 & 59.1 & 85.0 & 16.8 & 154 & 23.9 & 90.1 & 32.2 & 0.11 \\
\hline
\end{tabular}


TABLE IV (continuation)

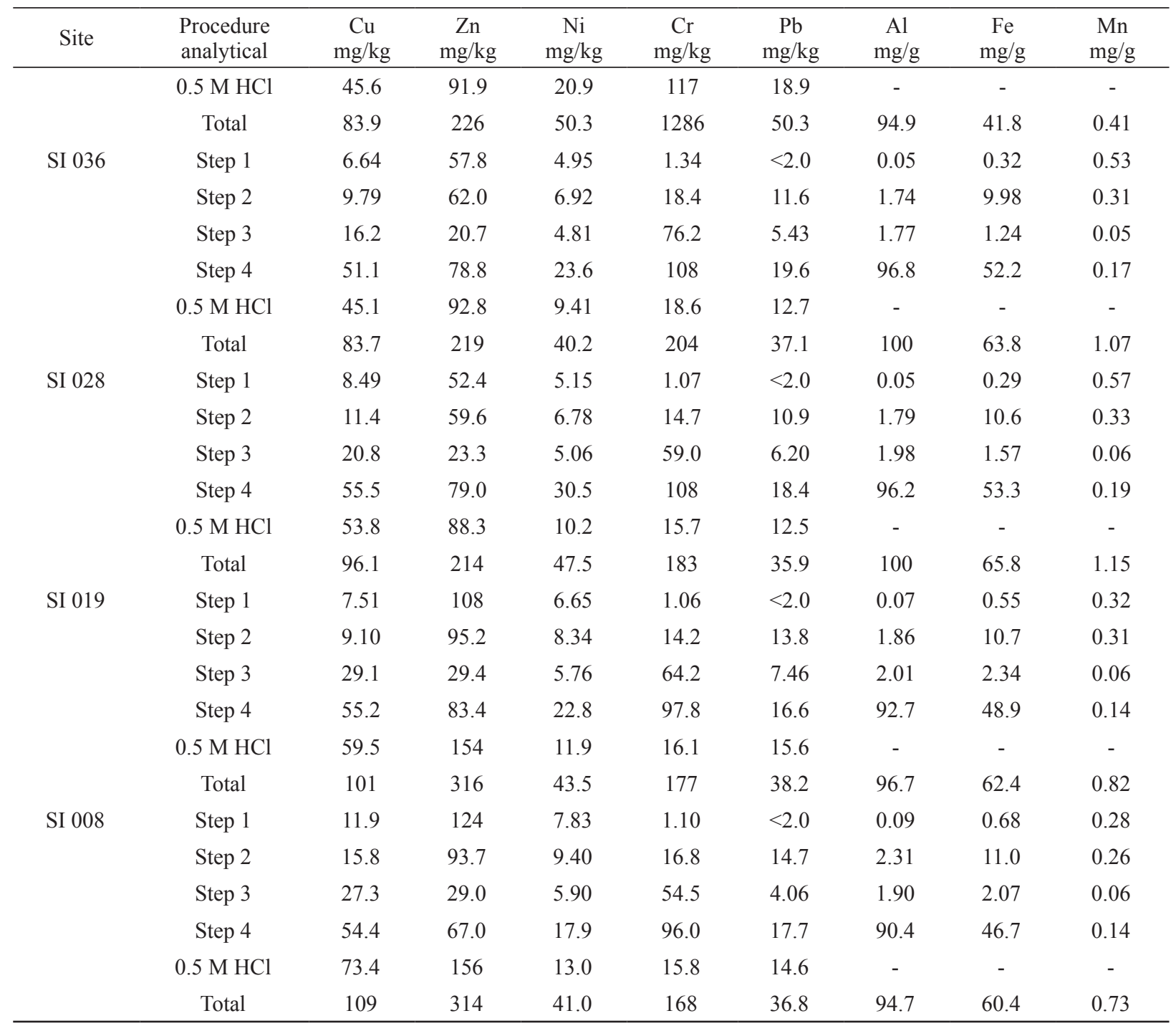

188 at the source of the Sinos River) to almost $80 \%$ at some sites (Luiz Rau stream, SI 019, and SI 008). $\mathrm{Zn}$ was extracted mainly from the exchangeable (1-41\%) and reducible (2-30\%) phases. In Hang's et al. study (2009), which evaluates the influence of electroplating industries, $\mathrm{Zn}$ was also extracted preferably in the exchangeable fraction. In the reducible step of the sequential extraction, $\mathrm{Zn}$ associated with $\mathrm{Fe}$ and $\mathrm{Mn}$ oxides, hydroxides and oxyhydroxides, capable of removing this metal from the aqueous phase (Boughriet et al. 2007), was also extracted mainly in this step as indicated by studies of Irabien and Velasco (1999), Rodrigues and Formoso (2006), Boughriet et al. (2007), Li et al. (2009), Liu et al. (2009), Vymazal et al. (2010), and Dundar's et al. (2012). Besides Zn and S appearance at the same statistical analysis factor, as mentioned above, proves $\mathrm{Zn}$ association to the sulfide oxidizable fraction form.

$\mathrm{Pb}$ total concentrations (Table IV) ranged from 25.4 to $59.5 \mathrm{mg} / \mathrm{kg}$, with highest levels found in the Luiz Rau and the Portão streams. The Pb geochemical distribution was associated with the reducible (19-40\%) and oxidizable (10-30\%) steps, 
indicating a potential average mobility of about $50 \%$. The $\mathrm{Pb}$ association to these phases has been reported by several authors e.g. Davidson et al. (1994, 2006), Kubová et al. (2008), Boughriet et al. (2007), Li et al. (2009), Vymazal et al. (2010), Davutluoglu et al. (2011), and Dundar et al. (2012). $\mathrm{Pb}$ oxidizable fraction presence may be due to the complex-metal formation with humic substances and/or metal sulfides insoluble in the sediments (Davutluoglu et al. 2011). It has also been reported that $\mathrm{Pb}$ can form stable complexes with $\mathrm{Fe}-\mathrm{Mn}$ oxides (Ramos et al. 1994, Liu et al. 2009). Anthropogenic $\mathrm{Pb}$ contributions arise from solid waste material containing batteries, electronic devices with $\mathrm{Pb} / \mathrm{Sn}$ solder, and from effluents of chemical, metal plating and paint industries (Tokalioglu et al. 2003, Oliveira et al. 2008, Dundar et al. 2012).

Total Mn concentrations (Table IV) varied a lot at the studied sites $(397-1,901 \mathrm{mg} / \mathrm{kg})$, especially at the Luiz Rau and the Portão streams, which showed the lowest concentrations. Mn showed a high degree of geochemical mobility at all sites (see Fig. 2 ), which is not necessarily due to anthropogenic contributions, but may also be due to environmental and geochemical regional characteristics (Teixeira et al. 2003, Rodrigues and Formoso 2006). It happens because $\mathrm{Mn}$ tends to be present in thermodynamically less stable phases in sediments as the exchangeable ion $\mathrm{Mn}^{2+}$, as easily reducible $\mathrm{Mn}$ oxides and as Mn trapped in carbonate minerals (Davidson et al. 1994, Robaina et al. 2002, Sakan et al. 2009). Mn was extracted mainly in the exchangeable (5$54 \%$ ) and reducible (11-37\%) fractions and showed a behavior similar to that in other studies (Davidson et al. 1994, Hang et al. 2009, Li et al. 2009, Liu et al. 2009, Davutluoglu et al. 2011, Dundar et al. 2012). Mn associated with the exchangeable fraction indicates that the metal is weakly adsorbed onto the sediment surface by relatively weak electrostatic interactions and that it can be easily released by ion exchange processes and dissociation of $\mathrm{Mn}$ bound to carbonates (Hang et al. 2009).
Total Ni concentrations (Table IV) showed no significant variations throughout the basin and varied from 35 to $54 \mathrm{mg} / \mathrm{kg}$. With regard to the $\mathrm{Ni}$ geochemical distribution (see Fig. 2), there was an increase in the potentially mobile fractions of this metal from site SI 066 onwards. Noteworthy are the high rates of mobility observed for the Luiz Rau and the Portão streams (about 70\%), probably in response to the wastewater from tanneries and electroplating industries. $\mathrm{Ni}$ was sequentially extracted in the three steps of the sequential extraction procedure: exchangeable (2-24\%), reducible (2-27\%) and oxidizable (3-24\%).

For $\mathrm{Cr}$, there was also an increase in total concentrations (Table IV) from the lower section of the Sinos River basin, varying between 112 and $1,286 \mathrm{mg} / \mathrm{kg}$. The concentration observed in the Portão stream $(1,286 \mathrm{mg} / \mathrm{kg})$ was higher than that of the other sites studied and well above the background level of the study area $(80.3 \mathrm{mg} / \mathrm{kg})$, set up by Robaina et al. (2002). As for the geochemical distribution of $\mathrm{Cr}$, we also observed an increase in the potentially mobile fractions (Fig. 2) from point SI 066 on. Cr was associated mainly with the oxidizable fraction, thus evidencing its preferential binding to organic matter (Rodrigues and Formoso 2006, Vymazal et al. 2010, Davutluoglu et al. 2011, Dundar et al. 2012). According to the data, $\mathrm{Cr}$ and OM appearance at the same statistical analysis factor (Table $\mathrm{V}$ ) proves a $\mathrm{Cr}$ preferred association to organic fraction of the sequential extraction procedure (step 3). The preferential association of $\mathrm{Cr}$ to the oxidizable phase indicated that most of that metal could be retained in the sediments in the trivalent state, less toxic, and bound to organic matter (Armienta et al. 1996, Wittbrodt and Palmer 1996). From the Portão stream, we extracted $1,039 \mathrm{mg} / \mathrm{kg}$ in the oxidizable step, equivalent to $81 \%$ of the total concentration of this metal. This high association of $\mathrm{Cr}$ to the oxidizable fraction is evidenced by the higher OM content in relation to other sites, see Table III. These high Cr levels are 
environmental markers of effluents from tanneries, as already reported by Rodrigues and Formoso (2006) and Oliveira et al. (2008), and they possibly reflect the influence of around 40 tanneries located in that region (FEPAM 2006).

In the present study, we found that the lower stretch of the Sinos River basin was the most affected area. Robaina et al. (2002) have already indicated that the sediments from the Luiz Rau stream were strongly affected by $\mathrm{Cr}$ (up to 1,050 $\mathrm{mg} / \mathrm{kg}$ ), $\mathrm{Cu}$ (up to $900 \mathrm{mg} / \mathrm{kg}$ ), $\mathrm{Zn}$ (up to $3,000 \mathrm{mg} /$ $\mathrm{kg}), \mathrm{Pb}(200 \mathrm{mg} / \mathrm{kg})$, and $\mathrm{Ni}$ (200 mg/kg), meaning highest pollution level according to the index adopted in that study. They also found metal levels in sediments of the main course of the Sinos River similar to those reported in this study. Oliveira et al. (2008) analyzed soil at two landfills near the Sinos River and found contamination from waste of leather industries and electroplating industries. They found concentrations of up to $1,744 \mathrm{mg} / \mathrm{kg}$ of $\mathrm{Cr}, 355 \mathrm{mg} / \mathrm{kg}$ of $\mathrm{Zn}, 94 \mathrm{mg} / \mathrm{kg}$ of $\mathrm{Cu}$, and 44 $\mathrm{mg} / \mathrm{kg}$ of Ni. They also pointed out the high levels of $\mathrm{Pb}$ (up to $70 \mathrm{mg} / \mathrm{kg}$ ), reported in the study as originating from the disposal of urban solid waste that may contain batteries, electronic devices with $\mathrm{Pb} / \mathrm{Sn}$ solder, material colored with lead paint, and packaging labels.

\section{EXTRACTION WITH $0.5 \mathrm{MOL} / \mathrm{L} \mathrm{HCl}$}

In this study, we evaluated $\mathrm{Cu}, \mathrm{Zn}, \mathrm{Ni}, \mathrm{Cr}$, and $\mathrm{Pb}$ potential mobile concentrations (Table IV) extracted by $0.5 \mathrm{~mol} / \mathrm{L} \mathrm{HCl}$ solution. As indicated by Sutherland and Tack (2008), it is possible to establish a linear regression between the concentrations extracted by $0.5 \mathrm{~mol} / \mathrm{L} \mathrm{HCl}$ and the sum of the first three steps of the sequential extraction procedure. The best linear regression was observed for $\mathrm{Zn}$ and is shown in Figure 3. Linear regressions found for the studied metals are shown in Table VI. All of them showed satisfactory $\mathrm{r}^{2}$ values: $\mathrm{Cu}\left(\mathrm{r}^{2}=0.9587\right), \mathrm{Zn} \quad\left(\mathrm{r}^{2}=0.9961\right), \mathrm{Ni}$ $\left(r^{2}=0.9762\right), \mathrm{Cr}\left(\mathrm{r}^{2}=0.9877\right)$ and $\mathrm{Pb}\left(\mathrm{r}^{2}=0.9049\right)$.
These regression relationships are encouraging as the $\mathrm{HCl}$ leach seems to be extracting the same suite of phases in the sediments as the BCR labile approach, but not to the same extent.

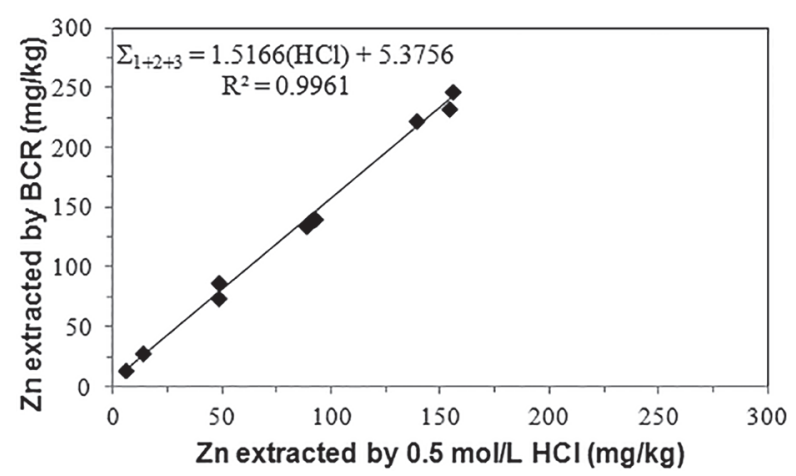

Fig. 3. Correlation between the $\mathrm{Zn}$ concentration extracted from sediment samples with $0.5 \mathrm{~mol} / \mathrm{L} \mathrm{HCl}$, and the sum of three labile phases extracted by sequential extraction procedure BCR $(n=10)$.

Thus, through this simple, fast $(1 \mathrm{~h})$ and low-cost extraction procedure, it is possible to identify the samples that show higher levels of potential mobile metals in sediments, derived from anthropogenic contributions. This screening of samples allows for a more careful evaluation of only the anthropogenically impacted samples, saving time, costs, and chemical reagents. However, before adopting the dilute $\mathrm{HCl}$ approach for all sediments, it is imperative to conduct a preliminary investigation to establish the degree of association between anthropogenic metals leached by dilute $\mathrm{HCl}$ and the potential mobile fractions liberated by the BCR approach. As an example, recent data from Cook and Parker (2006) indicates that this relationship may not hold for all environments. These authors found that the $0.5 \mathrm{M}$ $\mathrm{HCl}$ leach removed 35 times less $\mathrm{Pb}$ than the sum of the first three steps of the optimized BCR procedure for canal sediment contaminated by waste from a metal processing plant in France.

SEDIMENT QUALITY ASSESSMENT

Table VII shows the interval and average of the metal total concentrations for the Sinos River basin 
TABLE V

Pearson correlation coefficient for metals in the sediments along the Sinos River and tributaries.

\begin{tabular}{|c|c|c|c|c|c|c|c|c|c|c|}
\hline & $\mathrm{Cr}$ & $\mathrm{Cu}$ & $\mathrm{Ni}$ & $\mathrm{Pb}$ & $\mathrm{Zn}$ & $\mathrm{Al}$ & $\mathrm{Fe}$ & $\mathrm{Mn}$ & $\mathrm{S}$ & $\mathrm{MO}$ \\
\hline $\mathrm{Cr}$ & 1.000 & & & & & & & & & \\
\hline $\mathrm{Cu}$ & 0.040 & 1.000 & & & & & & & & \\
\hline $\mathrm{Ni}$ & 0.370 & 0.421 & 1.000 & & & & & & & \\
\hline $\mathrm{Pb}$ & 0.450 & $0.727^{*}$ & 0.356 & 1.000 & & & & & & \\
\hline $\mathrm{Zn}$ & 0.139 & $0.903^{* *}$ & 0.357 & $0.670^{*}$ & 1.000 & & & & & \\
\hline $\mathrm{Al}$ & 0.161 & $0.604^{*}$ & 0.687 & $0.710^{*}$ & 0.385 & 1.000 & & & & \\
\hline $\mathrm{Fe}$ & $0.655^{*}$ & $0.644^{*}$ & 0.107 & $0.874^{* *}$ & $0.737^{* *}$ & 0.431 & 1.000 & & & \\
\hline $\mathrm{Mn}$ & 0.473 & $0.643^{*}$ & 0.505 & $0.777^{* *}$ & $0.700^{*}$ & 0.442 & $0.719^{*}$ & 1.000 & & \\
\hline S & 0.280 & 0.346 & 0.059 & 0.054 & $0.638^{*}$ & 0.310 & 0.354 & 0.398 & 1.000 & \\
\hline MO & 0.555 & 0.098 & 0.058 & 0.126 & 0.053 & 0.144 & 0.197 & 0.357 & 0.492 & 1.000 \\
\hline
\end{tabular}

* Correlation is significant at the 0.05 level.

** Correlation is significant at the 0.01 level.

TABLE VI

Best-fit regression models correlating concentrations of metals from sediments and extracted by $0.5 \mathrm{~mol} / \mathrm{L} \mathrm{HCl}$, as well as the sum of the three labile phases extracted by sequential extraction procedure BCR $(n=10)$.

\begin{tabular}{ccc}
\hline Metal & Linear regression & $\mathrm{r}^{2}$ \\
\hline $\mathrm{Cu}$ & $\Sigma_{1+2+3}=0.8483(\mathrm{HCl})-5.0143$ & 0.9587 \\
$\mathrm{Zn}$ & $\Sigma_{1+2+3}=1.5166(\mathrm{HCl})+5.3756$ & 0.9961 \\
$\mathrm{Ni}$ & $\Sigma_{1+2+3}=1.5554(\mathrm{HCl})+2.4542$ & 0.9762 \\
$\mathrm{Cr}$ & $\Sigma_{1+2+3}=0.2278(\mathrm{HCl})-2.4881$ & 0.9378 \\
$\mathrm{~Pb}$ & $\Sigma_{1+2+3}=0.9854(\mathrm{HCl})+6.1679$ & 0.9049 \\
\hline
\end{tabular}

sediments, having a comparison between contents that were found in rivers by different experts. It also compares the background contents under the studies (Robaina et al. 2008) and the average shale (Turekian and Wedepohl 1961). Cr, Cu and $\mathrm{Zn}$ average concentrations, 254, 87.5 and 206 $\mathrm{mg} / \mathrm{kg}$, respectively, show concentrations above the taken area background and the average shale. The concentration intervals for these metals were similar to those found by Irabien and Velasco (1999), Oliveira et al. (2008), Li et al. (2009) for $\mathrm{Zn}$ and $\mathrm{Cu}$, and Rangel et al. (2011) for $\mathrm{Zn}$. During these studies, contaminated sediments were evaluated as originating from urban and industrial liquid waste, featuring similarities in the taken area. About $\mathrm{Cu}$ and $\mathrm{Cr}$ total concentrations were similar to those that were found by Rodrigues and Formoso
(2006) that evaluated Cadeia-Feitoria River basin sediments. This area is damaged by tanneries.

Ni concentrations, average $44.0 \mathrm{mg} / \mathrm{kg}$, were lower than background and shale ones. They have similar contents as those reported by Irabien and Velasco (1999), Rodrigues and Formoso (2006) and Rangel et al. (2011). Pb concentrations, average $37.0 \mathrm{mg} / \mathrm{kg}$, were lower than background ones, except for the Luiz Rau and the Portão streams, but they were higher than average shale. Above all, $\mathrm{Pb}$ concentrations were similar to Irabien and Velasco (1999), Davutluoglu et al. (2011) and Hang et al. (2009). Mn concentrations, average $1,081 \mathrm{mg} / \mathrm{kg}$, were classified as lower and higher considering background and shale levels, respectively. It must be considered that the concentrations were similar to Rodrigues and Formoso (2006) and Li et al. (2009).

Thereby, it is also important to mention that $\mathrm{Cr}, \mathrm{Cu}, \mathrm{Ni}, \mathrm{Zn}$ and $\mathrm{Pb}$ concentrations higher than the background levels found in the lower Sinos River are from industries, specially electroplating and metallurgical industries, tanneries and metal industries nearby, that send off liquid waste. Another important point to be taken into consideration is the number of people living in the area, and their liquid waste. This may also be affecting the increase of metal concentrations in the lower Sinos River. 
TABLE VII

Metals concentration $(\mathrm{mg} / \mathrm{kg})$ in the study area (minimummaximum) (average) compared with values from the literature.

\begin{tabular}{|c|c|c|c|c|c|c|c|}
\hline Location & $\mathrm{Cr}$ & $\mathrm{Cu}$ & $\mathrm{Ni}$ & $\mathrm{Zn}$ & $\mathrm{Pb}$ & $\mathrm{Mn}$ & Reference \\
\hline Sinos River & $\begin{array}{c}112-1,286 \\
254\end{array}$ & $\begin{array}{c}69.2-121 \\
87.5\end{array}$ & $\begin{array}{c}34.9-54.1 \\
44.0\end{array}$ & $\begin{array}{c}112-316 \\
206\end{array}$ & $\begin{array}{c}25.4-59.5 \\
37.0\end{array}$ & $\begin{array}{c}397-1,901 \\
1,081\end{array}$ & This study \\
\hline $\begin{array}{l}\text { Lower part of the } \\
\text { Sinos basin }\end{array}$ & $20.0-1,200$ & $20.0-1,175$ & $20.0-325$ & $50.0-5,300$ & $20.0-200$ & $*$ & $\begin{array}{c}\text { Robaina et al. } \\
2002\end{array}$ \\
\hline $\begin{array}{l}\text { Soil at two landfills } \\
\text { near the Sinos river }\end{array}$ & $205-1,744$ & $35.0-94.0$ & $13.0-44.0$ & $57.0-355$ & $23.0-70.0$ & $200-900$ & $\begin{array}{c}\text { Oliveira et al. } \\
2008\end{array}$ \\
\hline Cadeia River - Brazil & $34.7-423$ & $57.8-102$ & $27.0-74.9$ & $122-147$ & $*$ & $1,090-2,210$ & $\begin{array}{l}\text { Rodrigues and } \\
\text { Formoso } 2006\end{array}$ \\
\hline Feitoria River - Brazil & $169-1,031$ & $93.8-106$ & $71.2-91.1$ & $136-145$ & $*$ & $1,080-2,230$ & $\begin{array}{l}\text { Rodrigues and } \\
\text { Formoso } 2006\end{array}$ \\
\hline Estrela River - Brazil & $8.44-100$ & $10.0-74.5$ & $26.0-95.9$ & $42.5-351$ & $45.8-121.4$ & $164-811$ & $\begin{array}{c}\text { Rangel et al. } \\
2011\end{array}$ \\
\hline Sakarya river - Turkey & 37.0 & 37.5 & 83.0 & 76.7 & 41.3 & 772 & $\begin{array}{c}\text { Dundar et al. } \\
2012\end{array}$ \\
\hline Seyhan River - Turkey & $46.3-122$ & $3.68-57.2$ & $82.2-215$ & $34.2-146$ & $11.3-74.7$ & $144-638$ & $\begin{array}{l}\text { Davutluoglu et } \\
\text { al. } 2011\end{array}$ \\
\hline $\begin{array}{c}\text { Rivers in the Jiangsu } \\
\text { Province - Eastern } \\
\text { China }\end{array}$ & $345-9,671$ & $440-9,797$ & $251-2,846$ & $391-1,483$ & $17.2-106$ & $338-782$ & $\begin{array}{l}\text { Hang et al. } \\
2009\end{array}$ \\
\hline $\begin{array}{c}\text { Brunette River - } \\
\text { Canada }\end{array}$ & $*$ & $12.0-225$ & $*$ & $56.0-335$ & $63.0-722$ & $217-1,452$ & Li et al. 2009 \\
\hline $\begin{array}{l}\text { Deûle-canal - } \\
\text { Northern France }\end{array}$ & $*$ & $*$ & $*$ & $149-12,895$ & $26.8-10,079$ & $*$ & $\begin{array}{c}\text { Boughriet et al. } \\
2007\end{array}$ \\
\hline Oka River - Spain & $20.0-180$ & $30.0-150$ & $30.0-130$ & $100-360$ & $30-110$ & $370-1,600$ & $\begin{array}{c}\text { Irabien and } \\
\text { Velasco } 1999\end{array}$ \\
\hline Background & 80.3 & 39.4 & 50.5 & 82.4 & 42.0 & * & $\begin{array}{c}\text { Robaina et al. } \\
2002\end{array}$ \\
\hline Average shale & 90.0 & 45.0 & 68.0 & 95.0 & 20.0 & 850 & $\begin{array}{c}\text { Turekian and } \\
\text { Wedepohl } 1961\end{array}$ \\
\hline
\end{tabular}

* Not available.

Moreover, in order to evaluate sediment quality, Table VIII compares the average total metal concentration with sediment quality guidelines (SQGs) from Canada (CCME 1999) and with the study of Long et al. (1995). With regard to the Canadian study, it can be seen that $\mathrm{Cu}$ and $\mathrm{Cr}$ in the three stretches of the river basin, $\mathrm{Zn}$ in the upper and lower stretches, and $\mathrm{Pb}$ in the lower stretch, showed higher average concentrations than the interim freshwater sediment quality (ISQG) value. As for the probable effects level (PEL) criterion, only $\mathrm{Cr}$, in the lower stretch of the basin, showed higher average concentration. Considering the criteria of the study by Long et al. (1995), we see that the average concentrations of $\mathrm{Cu}, \mathrm{Ni}$ and $\mathrm{Cr}$ in the three stretches, and $\mathrm{Zn}$ and $\mathrm{Pb}$ in the lower stretch, were higher than the Effect Range Low (ERL) and Threshold Effects Level (TEL) concentrations. As for PEL, only the average levels of $\mathrm{Ni}$ and $\mathrm{Cr}$ in the lower basin were higher. There were no average concentrations higher than the effect range median (ERM) criterion. Therefore, based on the SQGs approach, the Sinos River basin would be classified as an area with free to moderate toxicological risk, when considering only the total concentration of metals, except the Portão stream, that showed moderate to high pollution.

\section{CONCLUSIONS}

The higher concentrations of $\mathrm{Cr}, \mathrm{Cu}, \mathrm{Zn}$ and $\mathrm{Pb}$ were observed in the lower stretch of the 
TABLE VIII

Comparison of average metal concentrations $(\mathrm{mg} / \mathrm{kg})$ in sediments of three stretches of the Sinos River basin with sediment quality guidelines (SQGs).

\begin{tabular}{cccccccccc}
\hline \multirow{2}{*}{ Metal } & \multicolumn{3}{c}{$\begin{array}{c}\text { Canadian Sediment } \\
\text { Quality Guidelines }\end{array}$} & \multicolumn{3}{c}{ Sediment quality guidelines $^{\mathrm{b}}$} & \multicolumn{3}{c}{$\begin{array}{c}\text { Average by stretch of the } \\
\text { Sinos River basin }\end{array}$} \\
\cline { 2 - 10 } & ISQG & PEL & TEL & PEL & ERL & ERM & Upper & Middle & Lower \\
\hline $\mathrm{Cu}(\mathrm{mg} / \mathrm{kg})$ & 35.7 & 197 & 18.7 & 108.2 & 43 & 270 & 72.0 & 69.2 & 93.6 \\
$\mathrm{Zn}(\mathrm{mg} / \mathrm{kg})$ & 123 & 315 & 124 & 271 & 150 & 410 & 127 & 112 & 238 \\
$\mathrm{Ni}(\mathrm{mg} / \mathrm{kg})$ & $*$ & $*$ & 15.9 & 42.8 & 20.9 & 51.6 & 46.6 & 41.5 & 43.6 \\
$\mathrm{Cr}(\mathrm{mg} / \mathrm{kg})$ & 37.3 & 90.0 & 52.3 & 160.4 & 81.0 & 370 & 116 & 116 & 306 \\
$\mathrm{~Pb}(\mathrm{mg} / \mathrm{kg})$ & 35.0 & 91.3 & 30.2 & 112.2 & 46.7 & 218 & 26.5 & 27.7 & 40.7 \\
$\mathrm{Al}(\mathrm{mg} / \mathrm{g})$ & $*$ & $*$ & $*$ & $*$ & $*$ & $*$ & 92.2 & 96.9 & 100 \\
$\mathrm{Fe}(\mathrm{mg} / \mathrm{g})$ & $*$ & $*$ & $*$ & $*$ & $*$ & $*$ & 86.0 & 81.2 & 60.7 \\
$\mathrm{Mn}(\mathrm{mg} / \mathrm{g})$ & $*$ & $*$ & $*$ & $*$ & $*$ & $*$ & 1.44 & 1.15 & 0.98 \\
\hline
\end{tabular}

${ }^{\mathrm{a}}$ CCME (1999), ${ }^{\mathrm{b}}$ Long et al. (1995), * Not available.

Sinos River basin sediment. This region, that has higher population density and industrial plants (mainly metal works, electroplating industries, and tanneries), showed an increase in both the total concentrations $(\mathrm{Cu}, \mathrm{Cr}, \mathrm{Zn}$ and $\mathrm{Pb})$ and in the sequentially extracted mobile fractions $(\mathrm{Cu}$, $\mathrm{Cr}$, Ni and $\mathrm{Zn}$ ). Cr pointed out, particularly in the Portão stream, showed $1,286 \mathrm{mg} / \mathrm{kg}$ as the total concentration and $88 \%$ in the potentially mobile fractions, due to the influence of the local tannery. These pollutants are available in the aquatic environment due to their association with different sediment phases.

The sequential extraction indicated that the metals were associated with the exchangeable $(\mathrm{Ni}$, $\mathrm{Zn}, \mathrm{Cu}$ ), reducible $(\mathrm{Ni}, \mathrm{Zn}, \mathrm{Cu}, \mathrm{Pb}$ ) and oxidizable phases $(\mathrm{Ni}, \mathrm{Cu}, \mathrm{Cr}, \mathrm{Pb})$. These results showed similar distribution with studies that evaluated sites impacted by the same anthropogenic sources. Regarding the sediment quality assessment, these regions can be classified as an area with free to moderate toxicological risk, except Portão stream, that showed moderate to high pollution.

Partial extractions are valuable tools for a preliminary survey, where critical contaminants and priority areas have to be identified. In our study, the potentially mobile metals extracted with a $0.5 \mathrm{~mol} / \mathrm{L} \mathrm{HCl}$ solution presented satisfactory correlation with the concentrations extracted by the sequential extraction scheme. Although some problems in the sequential extractions have not been fully resolved yet, the use of these procedures generate more complete information, enabling a more detailed characterization of the origin, chemical form, distribution, and metals potential availability. In this study the sequential extraction procedure demonstrated good reproducibility for the certified reference material (BCR 701) used.

Considering the factor analysis, it is possible to identify the main anthropogenic contributions in the Sinos River basin sediments. Further studies with geochemical focus are needed in order to have a better assessment of the potential retention and release of metals sediments, as well as to mineralogically feature the sediments in this area. Based on these studies, it will be possible to do an accurate assessment of the potential risk of metals contamination through their remobilization and the current condition of this study area with regards to these pollutants.

\section{ACKNOWLEDGMENTS}

We are grateful to Coordenação de Aperfeiçoamento de Pessoal de Nível Superior (CAPES) for granting the master's scholarship and to the Laboratory of Chemistry and Sampling Service of Fundação 
Estadual de Proteção Ambiental Henrique Luiz Roessler (FEPAM).

\section{RESUMO}

O presente estudo teve como objetivo avaliar o teor de $\mathrm{Cu}, \mathrm{Cr}, \mathrm{Ni}, \mathrm{Zn}, \mathrm{Pb}, \mathrm{Mn}, \mathrm{Al}$ e Fe e sua partição geoquímica em sedimentos da bacia hidrográfica do rio dos Sinos, Sul do Brasil. Esta bacia apresenta elevada densidade populacional e de indústrias, especialmente dos setores de metalurgia, galvanoplastia, siderurgia, petroquímica e curtumes. As concentrações totais de metais foram determinadas por fluorescência de raios- $\mathrm{X}$ e as concentrações nas fases dos sedimentos foram determinadas através da aplicação do esquema de extração sequencial BCR-701 proposto pelo Community Bureau of Reference, da Comunidade Europeia, utilizando ICP/OES. Também foram considerados os teores extraídos através de uma solução de $\mathrm{HCl}$ 0,5 mol/L. Os teores de metais foram avaliados na fração de sedimentos $<63 \mu \mathrm{m}$. Os resultados na região industrializada e com alta densidade populacional mostraram um aumento nas concentrações totais, para $\mathrm{Cu}, \mathrm{Cr}, \mathrm{Zn}$ e $\mathrm{Pb}$, e nas frações potencialmente móveis para $\mathrm{Cu}, \mathrm{Cr}, \mathrm{Zn}$ e Ni extraídos sequencialmente. $\mathrm{O} C r$ destacou-se especialmente no arroio Portão, apresentando uma concentração total de $1.286 \mathrm{mg}$ / $\mathrm{kg}$, devido à influência de curtumes localizados nesta região.

Palavras-chave: BCR-701, metais, sedimentos, extração sequencial.

\section{REFERENCES}

ARMienta MA, Rodríguez R, CENICEROS N, JUÁREZ F AND CRUZ O. 1996. Distribution, origin and fate of chromium in soils in Guanajuato, Mexico. Environ Pollut 91: 391-397.

BACON JF AND DAVIDSON CM. 2008. Is there a future for sequential chemical extraction? Analyst 133: 25-46.

Bevilacqua JE, Silva IS, Lichtig J AND Masini JC. 2009. Extração seletiva de metais pesados em sedimentos de fundo do Rio Tietê, São Paulo. Quim Nova 32: 26-33.

Boughriet A, Proix N, Billon G, ReCourt P AND OUdDane B. 2007. Environmental impacts of heavy metal discharges from a smelter in Deûle-canal sediments (Northern France): concentration levels and chemical fractionation. Water Air Soil Poll 180: 83-95.

CCME - CANadian Council of Ministers for the ENVIRONMENT. 1999. Canadian sediment quality guidelines for the protection of aquatic life: Summary tables. http:// st-ts.ccme.ca/
Comitesinos - Comitê de Gerenciamento da Bacia HidROGRÁFICA DO RIO DOS SINOS. 2009. Caracterização da bacia. http://www.comitesinos.com.br/

COOK SR AND PARKer A. 2006. Sequential extraction and single-step cold-acid extraction: A feasibility study for use with freshwater-canal sediments. Water Air Soil Poll 170: 95-105.

DAVIDSON CM, Ferreira PCS AND URE AM. 1999. Some sources of variability in application of the three-stage sequential extraction procedure recommended by BCR to industrially-contaminated soil. Fresen J Anal Chem 363: 446-451.

DaVidson CM, Thomas RP, MCVEy SE, PERALA R, LitTLEJOHN D AND URE AM. 1994. Evaluation of a sequential extraction procedure for the speciation of heavy metals in sediments. Anal Chim Acta 291: 277-286.

DAVIDSON CM ET AL. 2006. Fractionation of potentially toxic elements in urban soils from five European cities by means of a harmonized sequential extraction procedure. Anal Chim Acta 565: 63-72.

Davutluoglu OI, Seckin G, ERsu CB, Yilmaz T and SARI B. 2011. Heavy metal content and distribution in surface sediments of the Seyhan River, Turkey. J Environ Manage 92: 2250-2259.

Dundar MS, Altundag H, Eyupoglu V, Keskin SC AND Tutunoglu C. 2012. Determination of heavy metals in lower Sakarya River sediments using a BCR-sequential extraction procedure. Environ Monit Assess 184: 33-41.

FEPAM - FundaÇÃo EstaduAl DE PRoteÇão AmBIENTAL. 2006. Qualidade das águas da bacia hidrográfica do rio dos Sinos. http://www.fepam.rs.gov.br/qualidade/qualidade_ sinos/sinos.asp

Filgueiras AV, LAVILla I AND Bendicho C. 2002. Chemical sequential extraction for metal partitioning in environmental solid samples. J Environ Monitor 4: 823-857.

FöRSTNER U AND KERSTEN M. 1989. Assessment of metal mobility in dredged material and mine by pore water chemistry and solid speciation. In: SALOMON W AND FÖRSTNER U (Eds), Chemistry and Biology of Solid Waste: Dredged Material and Mine Tailings, Berlin: Springer-Verlag, p. 171-214.

Gleyzes C, Tellier S AND AstruC M. 2002. Fractionation studies of trace elements in contaminated soils and sediments: a review of sequential extraction procedures. Trend Anal Chem 21: 451-467.

Hang X, Wang H, Zhou J, Du C And Chen X. 2009. Characteristics and accumulation of heavy metals in sediments originated from an electroplating plant. J Hazard Mater 163: 922-930.

HoROwITZ AJ. 1991. A primer in sediment-trace element chemistry. Michigan: Lewis, $144 \mathrm{p}$.

IrABIEN MJ AND Velasco F. 1999. Heavy metals in Oka River sediments (Urdaibai National Biosphere Reserve, northern Spain): lithogenic and anthropogenic effects. Environ Geol 37: 54-63. 
JULIÁN PLL AND COLLADO JMM. 2002. Extracciones quimicas secuenciales de metales pesados. Aplicacion en ciencias geologicas. Estud Geol 58: 133-144.

Kubová J, Matús P, Budjos M, Hagarová I and Medved J. 2008. Utilization of optimized BCR three-step sequential and dilute $\mathrm{HCl}$ single extraction procedures for soil-plant metal transfer predictions in contaminated lands. Talanta 75: 1110-1122.

LARner BL, PALmer AS, SEen AJ AND Townsend AT. 2008. A comparison of an optimized sequential extraction procedure and dilute acid leaching of elements in anoxic sediments, including the effects of oxidation on sediment metal partitioning. Anal Chim Acta 608: 147-157.

LAYBAUER L AND BIDONE ED. 2001. Caracterização textural dos sedimentos de fundo do Lago Guaíba (Sul do Brasil) e sua importância em diagnósticos ambientais. Instituto de Geociências. Universidade Federal do Rio Grande do Sul, p. 13-26.

LI LY, HALl K, YUAN Y, MATTU G, MCCALLUM D AND CHEN M. 2009. Mobility and bioavailability of trace metals in the water-sediment system of the highly urbanized Brunette watershed. Water Air Soil Poll 197: 249-266.

LIU C, XU J, LIU C, ZHANG P AND DAI M. 2009. Heavy metals in the surface sediments in Lanzhou Reach of Yellow River, China. B Environ Contam Tox 82: 26-30.

LONG ER, MACDONALD DD, SMITH SL AND CALDER FD. 1995. Incidence of adverse biological effects within ranges of chemical concentrations in marine and estuarine sediments. J Environ Manage 19: 81-97.

López-SÁnchez JF, SAHUQuillo A, Fiedler HD, Rubio R, Rauret G, Muntau H AND Quevauvillier PH. 1998. CRM 601, a stable material for its extractable content of heavy metals. Analyst 123: 1675-1677.

MILLER JR. 1997. The role of fluvial geomorphic processes in the dispersal of heavy metals from mine sites. J Geochem Explor 58: 101-118.

Neue HU AND Mamaril CP. 1985. Zinc, sulphur and other micronutrients in wetland soils. In: Wetland soils: characterization, classification and utilization, Manila: International Rice Research Institute, p. 307-320.

OKORO HK, FATOKI OS, ADEKOLA FA, XIMBA BJ AND SNYMAN RG. 2012. A review of sequential extraction procedures for heavy metals speciation in soil and sediments. J Environ Anal Toxicol 1: 1-9.

Oliveira MTG, Rolim SBA, Mello-Farias PC, MENEGuZzi A AND LUTCKMEIER C. 2008. Industrial pollution of environmental compartments in the Sinos River Valley, RS, Brazil: geochemical-biogeochemical characterization and remote sensing. Water Air Soil Poll 192: 183-198.

Passos EA, Alves JPH, Garcia CAB AND Costa ACS. 2011. Metal Fractionation in Sediments of the Sergipe River, Northeast, Brazil. J Brazil Chem Soc 22: 828-835.

Pedrozo MFM. 2003. Cobre. In: DE AZEVEDo FA (Ed), Metais - Gerenciamento da Toxicidade, São Paulo: Altheneu, p. 143-184.
Pueyo M, Rauret G, LÜCK D, Yli-Halla M, Muntau H, QueVAuVILleR PH AND LÓPEZ-SÁNCHEZ JF. 2001. Certification of the extractable contents of $\mathrm{Cd}, \mathrm{Cr}, \mathrm{Cu}$, $\mathrm{Ni}, \mathrm{Pb}$ and $\mathrm{Zn}$ in a freshwater sediment following a collaboratively tested and optimized three-step sequential extraction procedure. J Environ Monit 3: 243-250.

QueVAuVILler PH, RAURET G, LÓPEZ-SÁNCHEZ JF, RuBIO R, URE A AND MunTAu H. 1996. The certification of the EDTA-extractable contents (mass fractions) of $\mathrm{Cd}, \mathrm{Cr}, \mathrm{Ni}$, $\mathrm{Pb}$ and $\mathrm{Zn}$ in sediment following a three-step sequential extraction procedure - EUR17554 EN. Louxembourg: Office for Official Publications of the European Communities, BCR Information.

Ramos L, Hernandez LM AND GOnZALEZ MJ. 1994. Sequential fractionation of copper, lead, cadmium and zinc in soil from or near Donana National Park. J Environ Qual 23: 50-57.

RANGEl CMA, BAPtista Neto JA, FonseCA EM, MCAlister J AND SMITH BJ. 2011. Study of heavy metal concentration and partitioning in the Estrela River: implications for the pollution in Guanabara Bay - SE Brazil. An Acad Bras Cienc 83: 801-815.

RAURET G. 1998. Extraction procedure for the determination of heavy metals contaminated soil and sediment. Talanta 46: 449-455

Rauret G, López-SÁNChez JF, SAHUQuillo A, Rubio R, DAVIDSON C, URE A AND QUEVAUVILLIER PH. 1999. Improvement of the BCR three step sequential extraction procedure prior to the certification of new sediment and soil reference materials. J Environ Monitor 1: 57-61.

Relic D, DordeVic D, Popovic A, JADRANIN M AND Polid P. 2010. Fractionation and potential mobility of trace metals in Danube alluvial aquifer within an industrialized zone. Environ Monit Assess 171: 229-248.

Robaina LE, Formoso MLL AND PIREs CAF. 2002. Metais pesados nos sedimentos de corrente, como indicadores de risco ambiental - Vale do rio dos Sinos, RS. Rev I Geol 23: $35-47$.

RODRIGUES MLK AND FORMOSO MLL. 2006. Geochemical distribution of selected heavy metals in stream sediments affected by tannery activities. Water Air Soil Poll 169: 167-184.

Rodrigues MLK, TeIXeIra EC, Franco DV, Grassi MT, ANJOS VE AND JARDIM WF. 2008. Especiação de metais em sedimentos. In: POLETO C (Ed), Ambiente e Sedimentos, Porto Alegre: ABRH, p. 229-290.

SAKAI H, KoJIMA Y AND SAITO K. 1986. Distribution of metals in water and sieved sediments in the Toyohira River. Water Res 20: 559-567.

SAKAN SM, DORDEVIC DS, MANOJLOVIC DD AND PREDRAG PS. 2009. Assessment of heavy metal pollutants accumulation in the Tisza River sediments. J Environ Manage 90: 3382-3390.

SALOMOnS W AND Förstner U. 1984. Metals in the Hydroclycle. Berlin: Springer-Verlag, 349 p. 
SALOMONS W AND STIGLIANI W. 1995. Biogeodynamics of Pollutants in Soils and Sediments. Berlin: SpringerVerlag, 352 p.

SCHUlte EE AND HopkINS BG. 1996. Estimation of soil organic matter by weight loss-on-ignition. In: MAGDOFF FR, TABATABAI MA AND HANLON EA (Eds), Soil Organic Matter: Analysis and Interpretation, Madison: Soil Science Society of America, p. 21-31.

SuTHERLAND RA. 2002. Comparison between non-residual Al, $\mathrm{Co}, \mathrm{Cu}, \mathrm{Fe}, \mathrm{Mn}, \mathrm{Ni}, \mathrm{Pb}$ and $\mathrm{Zn}$ released by a three-step sequential extraction procedure and a dilute hydrochloric acid leach for soil and road deposited sediment. Appl Geochem 17: 353-365.

SUTHERLAND RA AND TACK FMG. 2007. Sequential extraction of lead from grain size fractionated river sediments using the optimized BCR procedure. Water Air Soil Poll 184: 269-284.

SUTHERLAND RA AND TACK FMG. 2008. Extraction of labile metals from solid media by dilute hydrochloric acid. Environ Monit Assess 138: 119-130.

TEIXEIRA EC, RODRIGUES MLK, ALVES MFC AND BARBOSA JR. 2003. Study of geochemical distribution of heavy metals in sediments in areas impacted by coal mining. In: LOCAT J, GALVEZ-CLOUTIER R, CHANEY RC AND DEMARS K (Eds), Contaminated Sediments: Characterization, Evaluation, Mitigation/Restoration, and Management Strategy Performance, West Conshohocken: ASTM STP 1442, ASTM International, p. 72-86.
Tessier A, CAmpBell PGC AND BISSON M. 1979. Sequential extraction procedure for the speciation of particulate trace metals. Anal Chem 51: 844-850.

Tokalioglu S, Kartal S AND Birol G. 2003. Application of a three-stage sequential extraction procedure for the determination of extractable metal contents in highway soils. Turk J Chem 27: 333-346.

TUREKIAN KK AND WEDEPOHL KH. 1961. Distribution of elements in some major units of the earth's crusts. Geol Soc Am Bull 72: 175-192.

VYMAZAL J, SVEHLA J, KRÖPFELOVÁ L, NEMCOVÁ J AND SUCHY V. 2010. Heavy metals in sediments from constructed wetlands treating municipal wastewater. Biogeochemistry 101: 335-356.

WARREN LA AND HAACK EA. 2001. Biogeochemical controls on metal behavior in freshwater environments. Earth-Sci Rev 54: 261-320.

WiTTBRODT PR AND PALMER CD. 1996. Effect of temperature, ionic strength, background electrolytes, and Fe(III) on the reduction of hexavalent chromium by soil humic substances. Environ Sci Technol 30: 2470-2477. 